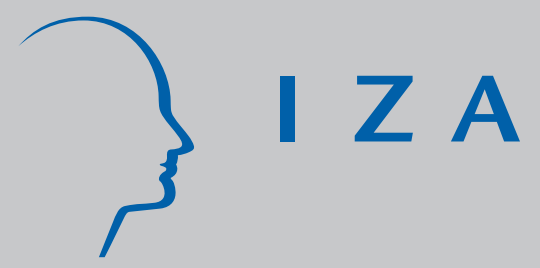

IZA DP No. 302

\title{
A Theory of Immigration Amnesties
}

\section{Gil S. Epstein}

Avi Weiss

J une 2001 


\title{
A Theory of Immigration Amnesties
}

\author{
Gil S. Epstein \\ Department of Economics, Bar-llan University, CEPR, London and IZA, Bonn \\ Avi Weiss \\ Department of Economics, Bar-Ilan University and IZA, Bonn
}

\author{
Discussion Paper No. 302 \\ June 2001
}

\author{
IZA \\ P.O. Box 7240 \\ D-53072 Bonn \\ Germany \\ Tel.: +49-228-3894-0 \\ Fax: +49-228-3894-210 \\ Email: iza@iza.org
}

This Discussion Paper is issued within the framework of IZA's research area Mobility and Flexibility of Labor Markets. Any opinions expressed here are those of the author(s) and not those of the institute. Research disseminated by IZA may include views on policy, but the institute itself takes no institutional policy positions.

The Institute for the Study of Labor (IZA) in Bonn is a local and virtual international research center and a place of communication between science, politics and business. IZA is an independent, nonprofit limited liability company (Gesellschaft mit beschränkter Haftung) supported by the Deutsche Post AG. The center is associated with the University of Bonn and offers a stimulating research environment through its research networks, research support, and visitors and doctoral programs. IZA engages in (i) original and internationally competitive research in all fields of labor economics, (ii) development of policy concepts, and (iii) dissemination of research results and concepts to the interested public. The current research program deals with (1) mobility and flexibility of labor markets, (2) internationalization of labor markets and European integration, (3) the welfare state and labor markets, (4) labor markets in transition, (5) the future of work, (6) project evaluation and (7) general labor economics.

IZA Discussion Papers often represent preliminary work and are circulated to encourage discussion. Citation of such a paper should account for its provisional character. 
IZA Discussion Paper No. 302

June 2001

\section{ABSTRACT}

\section{A Theory of Immigration Amnesties*}

This paper presents a first attempt at understanding some of the many issues involved in the granting of an amnesty to illegal immigrants. We consider government behavior with respect to allocations on limiting infiltration (border control) and apprehending infiltrators (internal control) and with respect to the granting of amnesties, the timing of amnesties, and limitations on eligibility for those amnesties. We demonstrate the effects of government actions on allocations and the flow of immigrants, and how the interactions between these factors combine to yield an optimal amnesty policy. We also consider various extensions such as intertemporal transfers of policing funds, risk-aversion, and "fuzziness" in declarations regarding eligibility for an amnesty aimed at apprehending and deporting undesirables.

JEL Classification: J61, J68, H59

Keywords: Amnesty, immigration, illegal immigration, border controls, internal controls

\section{Gil S. Epstein}

Department of Economics

Bar-llan University

52900 Ramat-Gan

Israel

Tel: $+972-3-531-8937$

Fax: $+972-3-535-3180$

Email: epsteig@mail.biu.ac.il

\footnotetext{
*We would like to thank Alessandra Venturini for helpful and useful comments.
} 


\section{Introduction}

Among the most hotly debated issues in economic and political circles worldwide are those regarding the effects immigrants have on host countries. There has been a myriad of economic articles written on the subject (see, for example, Borjas, 1994 and 1995, and Zimmermann, 1995 for excellent surveys), and it has been a central issue in numerous elections throughout the Western hemisphere. One thing is clear - except in unusual circumstances, ${ }^{1}$ Western countries tend to spend significant resources towards limiting the number and/or types of immigrants they allow into their countries. These limits are upheld via both border controls, through which undesired people are blocked from entering, and via internal enforcement, whereby undesired people are apprehended and expelled from the country (see, e.g., Ethier, 1986).

Despite these efforts, however, many illegal immigrants tend to find a way to slip through cracks in the system, if the benefit from doing so is sufficiently large. As a result, the more prosperous countries tend to find themselves in a position whereby, despite their best efforts, a stock of illegal immigrants accumulates and grows in their countries, and the government is incapable of apprehending and deporting these illegals. While there have been extensive debates about the effects legal immigrants have on an economy, there is little doubt that these illegal immigrants inflict a far greater burden on the host economy. This is because, aside from the burden legal migrants impose on a country, illegal migrants impose additional costs by the essence of their illegality, in that they tend not to pay taxes, and they are often involved in clandestine activities. This latter occurs due to their reluctance to enter the mainstream of the economy, and their inability to attain jobs in which they may be noticed.

One way countries have increasingly dealt with such problems is to periodically grant an amnesty to any worker who can demonstrate that he/she fulfills certain requirements (such as length of stay in the country, no criminal record, etc.). In these amnesties, workers who come forward are put through a procedure, at the end of which they are either "regularized" by being given some type of permit to remain (ranging from a one-year permit to citizenship) or expelled. Table 1 presents select

\footnotetext{
${ }^{1}$ There were instances in which immigration was not only not discouraged, but was actively sought. For example, in the middle of this century Germany was in dire need of workers, and actively sought temporary workers from neighboring countries. Many of these "temporary" workers remained in the country after contracts expired, and became a part of the large illegal immigrant population of
} 
information about amnesties over the past twenty years. As seen in this table, the number of illegal workers regularized has been quite significant, and there have been a number of countries that have had recurring amnesties over a fairly short period of time. Currently, in fact, there are ongoing discussions in the U.S., Italy, Greece, Israel and other Western countries about granting additional amnesties. In many instances, when countries grant these amnesties, they concurrently announce plans to clamp down on border controls.

This paper is the first attempt to our knowledge to develop a theory to explain amnesties. The focus will be on the host country, with the behavior of existing immigrants, potential future immigrants, and the government taken explicitly into account.

While there have been numerous studies of tax amnesties (see, for example, Malik and Schwab, 1991 and Andreoni, 1991) there are a few basic reasons why we cannot implement these results and models into the migration literature. First, a tax amnesty helps the authorities receive information about the illegal activities of different individuals and institutes. As a result of the amnesty the authorities can gain knowledge on methods used to evade taxes, and will be better placed to detect future illegal activities. This is not the case in migration amnesties, where there is little knowledge to be gained by authorities. While it may be argued that the authorities learn the origins of the illegal migrants, a fact that may help them allocate their border control budgets more efficiently, this information is in general already known to the authorities and is not the main objective. Second, one benefit from a tax amnesty is that the identity of the transgressor becomes known, which will tend to discourage him from future illegal activities of this sort, since the authorities are "wise to him." A legalized immigrant, however, will no longer have any incentive to become an illegal immigrant again. Third, a tax amnesty is backward looking in that with it authorities attempt to collect taxes owed from previous years, that might otherwise be lost. This element is not present in immigration amnesties, and it is only the future that is under consideration. Finally, immigration amnesties deal with people, and as such the amnesty has widespread implications such as externalities on other residents. This, of course, is what differentiates between labor economics and other branches of 
microeconomics. These important differences make tax and immigrant amnesties incompatible, although there are similarities in other aspects.

The reasons a country might not desire immigration, particularly of low-skilled workers, have been widely discussed (see, e.g., Borjas, 1994). As mentioned above, much of the supplementary objection to illegal immigration stems from the fact that illegal immigrants tend to be free riders - not paying their share of the tax burden while consuming public resources - and that because of their illegality they tend to be more involved in illicit activities, both by choice and when it is forced on them. ${ }^{2}$ Additional issues may include high social costs (schooling, health care, etc.) decreases in the wages of native workers, and effects on unemployment among natives, although these issues are pertinent for legal migrants also. Whether these costs exist and the magnitude of these costs are moot, yet the empirical observation that almost all countries limit immigration and try to keep illegals out, means, at the very least, that government officials believe there is some potential harm from allowing free migration. As a result, countries allocate considerable resources to agencies with the sole purpose of controlling immigration (e.g., the Immigration and Naturalization Service (INS) in the U.S.).

The next question then is, if illegal workers are indeed more of a burden to a country than legal immigrants, why not immediately legalize all those who manage to cross the border? The immediate answer to this question is that such a policy will affect the incentives of other foreigners to attempt to enter the country - an act that will surely increase illegal immigration. In addition, legalized workers cannot be thrown out, while apprehended illegal workers can be. Thus, the illegal status may be preferred in order to allow for apprehension and deportation. Finally, politicaleconomy reasons for keeping the workers illegal may exist, such as the benefit from having workers confined to certain sectors, which can be guaranteed in a democratic society only if they are illegal (Hillman and Weiss, 1999), or the benefit from having them largely unemployed for efficiency wage purposes (Epstein and Hillman, 2000).

The question then becomes, why have an amnesty at all? One justification could be to offset the negative effects increasing border and internal control expenditures

\footnotetext{
due to the low birth rate and the subsequent aging of the population.

${ }^{2}$ There are numerous instances of illegal workers being taken advantage of and being the victims of crimes.
} 
can have on a country. There exists a literature on the effects of these expenditures on the economy of the host country. Djajic (1999) examines the dynamic implications of border control policies and internal enforcement on illegal immigration, and the sectoral allocation of clandestine foreign workers. Myers and Papageorgiou (2000) present a model of a rich country with a redistributive public sector facing costly immigration control. They show that as border control becomes more expensive, inequality in the rich country increases.

Other reasons abound. First, the social costs from migrants may increase at a faster rate if the migrants are illegal than if they are legal. These social costs include illegals, as mentioned above, being involved in more crimes, both as felons and as victims. If this is so, there may be a critical mass at which point it becomes cheaper to legalize them than to continue bearing this additional cost. Second, the existence of a very large illegal base may signal the natives that illegality is acceptable and cause them to not pay taxes, for instance (since their illegal neighbors don't). Third, a large illegal immigrant presence may be a sign of impotence on the part of a government which may be harmful both domestically and internationally. Fourth, it may be considered inhumane to have such a large illegal population, many of whom live in poverty. Finally, an amnesty will increase the tax base.

For all these reasons, and many others, the system is as it is. The illegal immigration is unwanted, money is spent to keep them out, and, if they infiltrate, to find them and deport them. However, if these steps are not sufficiently successful, and the population of illegals grows too big, the country may be better off legalizing them. At that point an amnesty is offered, much of the illegal population becomes legalized, and the country shifts expenditures from internal controls (which becomes less necessary after the amnesty is granted) to more border controls. It is therefore not surprising that announcements of amnesties are often coupled with announcements about new measures taken to stop infiltration at the border.

The model will be presented as follows. In section II we first consider a country without an amnesty, and then show the effects of an amnesty. To this end, Section IIA begins with a country to which an exogenous number of people would like to immigrate, and considers the optimal manner in which the country should allocate its resources to controlling illegal immigration, when its options are spending funds on 
border control or on internal control. The former is earmarked towards stopping infiltration by illegals, and the latter towards apprehending individuals who managed to infiltrate. We show how the stock of illegal immigrants grows over time, and find the steady-state number of illegal immigrants.

Section IIB takes a more careful look at the migrants and their incentives. A model is presented in which the decision to migrate depends upon relative wages and the probability of being caught and deported. We show how the different parameters, including allocations to border and internal control, affect the size of the flow of migrants. This behavior by potential migrants feeds back into governmental allocation decisions, and a revised steady-state level of illegal migrants is derived.

We then turn in Section IIC to amnesties. We show how an amnesty affects the stock and flow of illegal immigrants, and, in turn, the cost to the country of these migrants. The cost is divided into two parts - the cost of the migrants who have been legalized, and the cost of the migrants who will arrive after the amnesty. One of the central issues is the effect an amnesty will have on migrant expectations. In particular, if potential migrants believe that amnesties will recur, the flow of migrants into the country will increase, implying a larger cost to the country. We demonstrate how the optimal time of an amnesty is determined, and show the conditions necessary for this to be an equilibrium.

Section IID considers the possibility of a delayed amnesty, under which only those in the country for a certain minimum number of years or more are eligible for the amnesty, is considered. We show how this feeds back into potential migrant decisions, and, consequently, into costs, and demonstrate the tradeoff from such a plan.

Section IIE looks at a limited amnesty, in which illegal workers who come forward are granted a work permit for a fixed period, after which they are forced to return to their home country. Enforcement of the time period can be guaranteed by use of a bond deposited by the migrant or by someone willing to vouch for him. One of the effects of this plan is that some of the illegal immigrants do not make use of the amnesty, as it is preferable for them to remain in the country illegally, and take their chances that they will not be caught quickly. 
Section III considers some extensions to the model, including intertemporal transfers of control budgets, risk aversion and uncertainty. Our discussion on uncertainty stems from an empirical peculiarity. One of the results of many amnesties is that some applicants are refused amnesty, and are then deported. If the criteria for receiving the amnesty are well known, we would not expect anyone to be expelled as a result of the amnesty, since all those who would be expelled would not step forward. For expulsions to exist the criteria must be unclear, and the reason immigrants come forward nonetheless is that their expected gain exceeds their expected loss. Thus, amnesty programs can also be a mechanism for ridding the country of some undesirables.

In Section IV we summarize.

\section{The Model}

\section{$\underline{\text { A. Border vs. Internal controls }}$}

Consider a country into which $m_{i}$ individuals want to migrate in year $i$. For the present $m_{i}$ is treated as exogenous, but this treatment is changed below where its determinants are discussed. Denote by $M_{i}$ the stock of migrants in the country at the end of year $i$, and assume, for simplicity, that initially, in period 0 , there are no migrants, so that $M_{0}=0$. In the absence of efforts to hinder such immigrants from entering and residing in the country, the stock of illegal immigrants in the country at the start of period t will simply be $M_{t}=\sum_{i=1}^{t-1} m_{i}$.

The government has at its disposal in year $i$ a budget $E_{i}$ earmarked for immigration control. Following Ethier (1986) expenditures can be bifurcated into expenditures for border controls and those for internal controls, where the former refers to expenditures aimed at keeping illegal immigrants from entering the country, and the latter refers to expenditures aimed at apprehending illegals who managed to enter the country despite the border controls. We therefore write $E_{i}^{B}+E_{i}^{I}=E_{i}$, where $E_{i}^{B}$ are expenditures in period $i$ on border controls and $E_{i}^{I}$ are expenditures on internal controls. We further assume, for simplicity only, that the time sequence is such that expenditures on internal controls are effective only in apprehending illegals 
who are already in the country at the start of the period, and not for entrants during that period. Note that under these conditions all expenditures on immigration control in period 1 will be on border controls alone, since there is no stock of immigrants to attempt to apprehend and extradite. Thus, $E_{1}^{B}=E_{1}$.

These expenditures are productive in preventing infiltration and in apprehending infiltrators. Let $P_{i}^{B}\left(E_{i}^{B}\right)$ and $P_{i}^{I}\left(E_{i}^{I}\right)$ denote the percentage of illegals apprehended at the border and internally in year $i$, respectively, with $\left(P_{i}^{j}\right)^{\prime}>0,\left(P_{i}^{j}\right)^{\prime \prime}<0, P_{i}^{j}(0)=0$, and $P_{i}^{j}(\infty)=1, j=B, I{ }^{3}$ Given this, the stock of illegals in the country in any given year is given by

$$
M_{t}=\left(1-P_{t}\left(E_{t}\right)\right) m_{t}+\left(1-P_{t}\left(E_{t}\right)\right) M_{t-1} \cdot
$$

Solving this recursively:

$$
M_{t}=\sum_{i=1}^{t} m_{i}\left(1-P_{i}^{B}\left(E_{i}^{B}\right)\right) \prod_{j=i+1}^{t}\left(1-P_{j}^{I}\left(E_{j}^{I}\right)\right) .
$$

The government's objective function (assuming no discounting for simplicity) is assumed (for now) to be to minimize a weighted average of the stock of migrants over a certain (possibly infinite) period, i.e., to

$$
\begin{gathered}
\underset{E_{i}^{B}, E_{i}^{I}}{\operatorname{Mi}} \sum_{i=1}^{T} \alpha_{i} M_{i}=\underset{E_{i}^{B}, E_{i}^{I}}{\operatorname{Min}}\left[\alpha_{1} m_{1}\left(1-P_{1}^{B}\left(E_{1}^{B}\right)\right)+\sum_{k=2}^{T} \alpha_{k} \sum_{i=1}^{k} m_{i}\left(1-P_{i}^{B}\left(E_{i}^{B}\right)\right) \prod_{j=i+1}^{k}\left(1-P_{j}^{I}\left(E_{j}^{I}\right)\right)\right] \\
\text { s.t. } \sum_{k=1}^{T} \alpha_{k}=1 ; \\
\alpha_{k} \geq 0 \forall k ; \\
E_{i}^{B}+E_{i}^{I} \leq E_{i} \forall i ; \\
E_{i}^{l} \geq 0 \forall i, l .
\end{gathered}
$$

To understand this equation, note that the stock of illegals in the country in period $k$ depends on the flow in period $i$ multiplied by the percentage of immigrants that managed to infiltrating the border that year, $1-P_{i}\left(E_{i}\right)$, and by the probability that they were not caught in the subsequent $k$-i years, $\prod_{j=i+1}^{k}\left(1-P_{j}^{I}\left(E_{j}^{I}\right)\right)$. From this we can derive the following lemma.

\footnotetext{
${ }^{3}$ Our assumption is that the percentage caught depends on expenitures and not the number of those caught. This assumption may be extreme, but it conveys the idea that the greater the stock, the easier it is to find illegals - "like shooting fish in a barrel."
} 
Lemma 1: Allocations between internal and border controls are independent of time preferences.

Proof: What this lemma states is that the weights do not effect the allocation of resources. To see this, replace the third constraint into the objective function by rewriting this constrain as $E_{i}=E_{i}-E_{i}$. Consider the effect of transferring expenditures from internal control to border control in period i. Clearly, from the first statement in (3), this will not effect the stock of illegals prior to period i. Thus, the change can be written as follows:

(4) $\frac{\partial \Phi}{\partial E_{i}^{B}}=\sum_{j=1}^{T-i} \alpha_{j} \frac{\partial M_{i+j}}{\partial E_{i}^{B}}$,

where $\Phi$ denotes the objective function. Applying (1) repeatedly:

(5) $\frac{\partial M_{i+j}}{\partial E_{i}^{B}}=\prod_{j=1}^{T-i}\left(1-P_{i+j}^{I}\right) \frac{\partial M_{i}}{\partial E_{i}^{B}}$.

Hence, the first order condition for a maximum is (using 1):

(6) $\left[\sum_{k=1}^{T-i} \alpha_{i+k} \prod_{j=1}^{k}\left(1-P_{i+j}^{I}\right)\right]\left(\left(P_{i}^{B}\right)^{\prime} m_{i}-\left(P_{i}^{I}\right)^{\prime} M_{i-1}\right)=0$.

Note that the term in the square brackets is clearly positive, so the allocations will be made optimally so that the term in the rounded brackets will equal zero. Since the weights $\alpha_{i}$ do not appear in the rounded brackets, the choice of allocation of funds in any year $i$ is independent of these weights, as per Lemma $1 . \quad$ Q.E.D.

The logic behind this finding is that since the budget is fixed, and the stock existing at the end of one period is passed on to the subsequent period, allocating resources to minimize the stock in one period will automatically minimize the stock in future periods also, since a smaller stock is being passed on. The message from this Lemma is that the optimization problem as specified is sensible for deciding how to allocate resources between these two uses, since as long as a small stock is desired, the government will act as prescribed by (3) with respect to allocations between border and internal controls, independent of its actual objective function. 
From (3) we also get

Lemma 2: The larger the stock relative to the flow, the more resources will be allocated to internal control.

Proof: The first order condition in (6) can be rewritten as

(7) $\frac{\left(P_{i}\right)^{\prime}}{\left(P_{i}\right)^{\prime}}=\frac{M_{i-1}}{m_{i}}$.

Since the left hand side of (7) is a decreasing function of $E_{i}$, the result in the Lemma follows.

Q.E.D.

This result is intuitive, and has the following implications. Assume that the probability functions are such that the stock is initially (in period 1) growing. This amounts to assuming that

$$
\text { (8) } \Delta M_{2}=\left(1-P_{2}^{B}\right) m_{2}-P_{2}^{I} M_{1}>0 \text {. }
$$

The first term is the inflow of migrants, and the second term is those being deported from among the migrants who made it passed the border in period 1. If (8) holds, then the stock will continue to grow initially. Assuming a nonincreasing flow over time, Lemma 2 says that this will lead to less border control and more internal control in order to lower the stock. If the flow of migrants becomes constant a steady state will exist when

(9) $\left(1-P_{i}\right) m_{s}-P_{i} M_{s}=0$,

at which point funds will no longer be shifted from border to internal controls. Clearly, however, the level of the stock in the steady state will depend on the level of the flow at that steady state. The determinants of this flow are the subject of the next sub-section.

\section{B. The Migrants}

We turn now to consider the migrants. The incentive for them to migrate is the wage differential between their home country and the host country. This differential 
must be great enough to outweigh the cost of being deported if caught. ${ }^{4}$ In what follows we assume for simplicity that potential migrants are risk neutral.

There are Q heterogeneous workers in the source country each year who are interested in migrating. Wages vary across workers, with the distribution of source country wages by potential migrants given by $W_{i}^{S} \sim\left(0, W^{I}\right)$, where $W^{I}$ is the wage received in the host country as an illegal immigrant. $g\left(W_{i}^{S}\right)$ is the pdf and $G\left(W_{i}^{S}\right)$ the cdf of the wage distribution. Anyone earning more than $W$ in the source is not a potential migrant. The cost of being deported is denoted by $C_{D}$. Workers will migrate if their expected income in the host country during their $N$ years in the workforce is greater than the expected income in the source country over the same period. ${ }^{5}$ For simplicity we assume no discounting.

Worker $i$ 's lifetime wage in the source country is simply $V_{i}^{S}=N W_{i}^{S}$. In the host country the expected wage depends on the probability of being caught and deported. For worker $i$ in period $e$ this is given by:

$$
V_{i}^{H}(e)=N W_{i}^{S}+\left(1-P_{e}\right)\left[\left(1+\sum_{h=1}^{N-1} \prod_{=1}^{h}\left(1-P_{e+}\right)\right)\left(W-W_{i}^{S}\right)-C_{D}\left(1-\prod_{=1}^{N-1}\left(1-P_{e+}\right)\right)\right] .
$$

The first term equals the wage in the source country, so that the remainder is the wage premium from migration. This premium, $\left(W^{I}-W_{i}^{S}\right)$, is achieved only if the worker manages to slip through the border controls which happens with probability $\left(1-P_{e}^{B}\right)$. $\prod_{k=1}^{i}\left(1-P_{e+k}^{I}\right)$ represents the probability of still being in the country in year $i$, and $1+\sum_{h=1}^{N-1} \prod_{k=1}^{h}\left(1-P_{e+k}^{I}\right)$ is the sum of these probabilities over the $N$ years. Note in particular the 1 in this equation stems from the fact that the migrant will receive the

\footnotetext{
${ }^{4}$ For simplicity, we do not include a migration cost (pecuniary or non-pecuniary, with an example of the latter being the emotional cost of leaving home and ones loved ones). Thus, the assumption is that an unsuccessful migrant can simply return home without any penalty. There might, however, be a cost for the successful migrant, who is placed in unfamiliar surroundings. This could be incorporated in the model by removing this cost from the first period wages if he gets passed the border controls. This woul not effect the results.

${ }^{5}$ Note that the calculations in the previous Section implicitly assumed that workers are infinitely lived, while here we assume workers have a finite work-life. These can be reconciled if workers bear offspring, but are concerned only with their own welfare (i.e., they are not altruistic).
} 
premium in the first period with certainty since internal controls are relevant only for those in the country the prior year (by definition). The final term is the expected cost of being deported, with $\left(1-\prod_{k=1}^{N}\left(1-P_{e+k}^{I}\right)\right)$ being the probability of being deported at some time in the future.

All workers for whom $V_{i}^{H}>V_{i}^{S}$ will attempt to migrate. Thus, the flow of migrants in period 1 will be given by:

$$
m_{e}=Q G\left(W^{I}-\frac{C_{D}\left(1-\prod_{k=1}^{N-1}\left(1-P_{e+k}^{I}\right)\right)}{\left(1+\sum_{h=1}^{N-1} \prod_{k=1}^{h}\left(1-P_{e+k}^{I}\right)\right)}\right)
$$

Note that, quite naturally, an increase in internal control in future periods will lower the number of migrants attempting to enter the country. Thus, taking into consideration the behavior of the governemnt as described in the preious section, we arrive at the following proposition:

Proposition 1: Beginning from an initial stock of migrants below the steady state level, the flow of migrants will decrease over time.

Proof: Recall from Lemma 2 that if the stock relative to the flow increases, more resources will be allocated to internal control. Assume a constant flow. If we begin with a stock below the steady-state for that size flow, (8) will hold, and the stock will grow. Then, from Lemma 2, future allocations to border control will decrease in favor of increased allocations to internal control. As a result, from (11), the flow will fall.

$$
\text { Q.E.D. }
$$

With the flow falling but the stock rising, a steady-state will be approached, and it will be reached when (9) holds, at which point allocations and flows will remain constant. This steady state is shown in the two panels of Figure 1. The top panel shows how allocations are changing over time, and the bottom panel shows the implications for the stock and flow of migrants over time. Both show the steady-state levels of the variables. 


\section{An Amnesty}

To understand the effect of an amnesty, we first consider how the expectation of an amnesty will affect the flow of migrants, and then show the consequences of an amnesty for the host country. Given these consequences, we show how the optimal timing of an amnesty is determined.

Assume, then, that a country decides to grant an amnesty once every $A$ years. ${ }^{6}$ For this to be an equilibrium, each party must be aware of the incentives and reactions of the other party, and must take these into account in choosing actions. Thus, in equilibrium, the timing of an amnesty (if any) is set by the government after taking into account the reaction of potential migrants to this timing, and migrants, in turn, know the governments objective function, and thus know when the amnesty will occur. After an amnesty workers become legal and can no longer be deported. The expected lifetime income of a person considering immigrating $e$ periods before the amnesty will increase from (10) to: ${ }^{7}$

$$
\begin{aligned}
& V_{i}^{H}(e)=N W_{i}^{S} \\
& \quad+\left(1-P_{e}^{B}\right)\left[\left(1+\sum_{h=1 k=1}^{e} \prod_{k=1}^{h}\left(1-P_{e+k}^{I}\right)+(N-e)\right)\left(W^{I}-W_{i}^{S}\right)-C_{D}\left(1-\prod_{k=1}^{e}\left(1-P_{e+k}^{I}\right)\right)\right]
\end{aligned}
$$

and the number of workers migrating will increase from (11) to:

$$
m_{e}=Q G\left(W^{I}-\frac{C_{D}\left(1-\prod_{k=1}^{e}\left(1-P_{e+k}^{I}\right)\right)}{\left(N+1-e+\sum_{h=1}^{e} \prod_{k=1}^{h}\left(1-P_{e+k}^{I}\right)\right)}\right)
$$

This occurs for each cohort of potential immigrants from amnesty to amnesty, or, if the length between amnesties is greater than the work-life of the immigrant, for the last $N$ years before an amnesty.

Note that if expenditures on internal control are kept constant over time, the flow of migrants into the country is going to increase as the amnesty approaches (as $e$ gets smaller). This is in direct contrast to Proposition 1. Even if, as per Lemma 2, expenditures on internal control rise over time, it is likely that the positive effect of

\footnotetext{
${ }^{6}$ The length of time between amnesties will be constant in equilibrium because the problem always looks identical after each amnesty, as developed below.

${ }^{7}$ Note we have assumed that the migrant's wage does not change after becoming legal. There is good reason to believe, however, that this wage would increase, as the employment options facing the legal migrant are far vaster than those facing an illegal immigrant. This increased wage would have the effect of further increasing the flow of immigrants as the amnesty date approaches.
} 
the approaching amnesty, and the benefits to be realized if the migrant manages to escape detection until then, will outweigh the negative effect of increased internal control. Thus, Lemma 2 and Proposition 1 are most likely reversed if an amnesty is known to be forthcoming. The stock of migrants is demonstrated in Figure 2, in which the amnesty periods are marked. Note that the presence of an amnesty makes the shape of the curve between amnesties different from that presented in Figure 1.

Having shown the effect of an amnesty on potential migrants, we turn now to the government's decision to enact such an amnesty. In choosing whether and when to grant an amnesty, the government, for its part, must take into account not only the higher per period cost illegal immigrants inflict on the economy, but also the effect an amnesty will have on future immigration waves, as demonstrated above, and the fact that an illegal worker can be deported, while a legal worker cannot.

We first posit the following:

Proposition 2: The longer the length of time between amnesties, the larger will be the stock of illegal migrants prior to the amnesty.

Proof: Proof by contradiction. Consider amnesties after $A$ and $A+1$ periods, denoted the $A$-regime and the $A+1$-regime, respectively. In the period just before the amnesties, which we denote period $T$, the flow will be equal under the two regimes, since all $Q$ workers will want to attempt entry into the country (since, if they get passed the border controls, they cannot be thrown out). If the stock of migrants under the two regimes is also equal, then by Lemma 2 allocations between internal and border controls will be identical. Returning to period $T-1$, the flows will again be equal because of the identical allocations in the last period. As a result, allocations will also be identical under the two regimes in period $T-1$. This can be continued until the period $T-A$. However, in period $T-A$ the stock under the $A$-regime is by definition 0 (since an amnesty was just declared) while that in the $A+1$-regime is positive because of the migration in the preceding period. Thus, the stocks cannot be equal in period $T$.

Assume now that the stock in period $T$ is larger under the $A$-regime than under the $A+1$-regime. In this case the flow in period $T-1$ will be smaller in the $A$-regime, so to get a larger stock in period $T$, an even larger stock must have remained form period 
$T-1$. Continuing, as in the previous paragraph, to period $T-A$, the stock in this period will have to be greater in the $A$-regime, which is impossible. Thus, the proposition holds.

Q.E.D.

This proposition is not obvious since the longer period before the amnesty will lead to smaller flows of migrants, and this effect had the potential to lead to a lower total illegal presence. From the proof it is clear why this does not occur. This proposition now allows us to consider all of the issues involved in choosing the optimal timing of an amnesty. The government's quest is to allocate resources (on border and internal controls) and to set policy (on the frequency of amnesties) in order to minimize the cost to the country from these immigrants. Allocations of resources are as derived above in Section IIA. An amnesty, however, entails a tradeoff. On the one hand, illegal immigrants are more costly to the country than if they were legalized, for the reasons discussed in the introduction. We denote the yearly cost of $M$ illegal workers $C_{I}(M)$ and of $M$ legal workers $C_{L}(M)$, with $C_{I}(M)>C_{L}(M)$. Hence, the earlier the amnesty the less costs the country must bear from migrants already in the country. On the other hand, once a worker is legalized he can no longer be expelled, and the earlier the amnesty, the larger the flow of migrants (as developed above). Thus, for instance, if an amnesty is granted each year there is no cost from illegality (although there is a cost from the legal migrants), but all foreign workers with salaries below those paid locally will desire to migrate, and if they get passed the border controls they will forever remain.

We now develop the conditions necessary for an amnesty once every $A$ years to be optimal and an equilibrium. Assume the economy is at a point at which it must decide whether to grant an amnesty ( $A$ years after the last amnesty). Recall from the discussion above that the flow, and thus the stock, of illegal migrants depends on the allocation of expenditures on border and internal controls, and on the length of the amnesty period. The government takes this relationship into account in determining these parameters. We thus define the cost of illegal immigrants at period $j$ given an amnesty period of $A$ as $C_{I}\left(M_{j}(A)\right)$, and the cost of the same number of legal workers as $C_{L}\left(M_{j}(A)\right)$. At period $A$, when the government is considering granting an amnesty, the 
cost of the existing and all future illegal immigrants that will result from a policy of amnesties every $A$ periods is given by:

$$
C(A)=\frac{C_{L}\left(M_{A}(A)\right)}{1-\delta}+\sum_{i=1}^{A-1} \delta^{i} C_{I}\left(M_{i}(A)\right)+\delta^{A} C(A),
$$

where $\delta$ is the discount rate. The first term is the present value of the cost to the economy of those workers who have been legalized and will now remain in the country indefinitely. The second term is the cost of all those immigrants who arrive between this amnesty and the next amnesty. The final term reflects the fact that the problem the government faces before this amnesty is identical to the one it will face before the next amnesty. This will be strictly true only if the cost of legal migrants is linear in the number of migrants, since, in reality, after the next amnesty there will be more legal migrants than after the initial amnesty. Solving (14), we get:

(15) $C(A)=\frac{C_{L}\left(M_{A}(A)\right)}{(1-\delta)\left(1-\delta^{A}\right)}+\sum_{i=1}^{A-1} \frac{\delta^{i}}{\left(1-\delta^{A}\right)} C_{I}\left(M_{i}(A)\right)$.

For $A$ to be an optimal amnesty frequency, it must be the case that having an amnesty once every $A$ periods is no more costly than having one once every $B$ periods. This amounts to requiring that:

$$
\frac{C_{L}\left(M_{A}(A)\right)}{(1-\delta)\left(1-\delta^{A}\right)}+\sum_{i=1}^{A-1} \frac{\delta^{i}}{\left(1-\delta^{A}\right)} C_{I}\left(M_{i}(A)\right) \leq \frac{C_{L}\left(M_{B}(B)\right)}{(1-\delta)\left(1-\delta^{B}\right)}+\sum_{i=1}^{B-1} \frac{\delta^{i}}{\left(1-\delta^{B}\right)} C_{I}\left(M_{i}(B)\right) .
$$

As shown in Proposition 2, the stock of immigrants will be greater in the final, and each intermediate, period the longer the amnesty period. Thus, if $B>A$ this will tend to make the RHS larger than the LHS. However, legalization occurs less often, which leads to two benefits from a later amnesty - lower costs from legalized aliens because of the less frequent amnesties (this is witnessed by the larger discount factor in the denominator of the first term on the RHS), and by the additional period of a low stock of illegal migrants when the amnesty frequency is lengthened.

For $A$ to also be an equilibrium amnesty frequency it must not be worthwhile for the government to "fool" migrants. In other words, given that consumers believe that an amnesty will occur after $A$ periods, it must not beneficial for the government to either proclaim an amnesty a year earlier or to push the amnesty off for an additional year. To evaluate this, we assume that potential migrants can be fooled only once, and that if, for instance, an amnesty is pushed off by one year, migrants will then believe 
that amnesties will occur only once every $A+1$ periods. We consider the possibilities of delaying the amnesty by one year or of bringing the amnesty forward by one year. These conditions amount to:

$$
\begin{aligned}
& \frac{C_{L}\left(M_{A}(A)\right)}{1-\delta}+\sum_{i=1}^{A-1} \delta^{i} C_{I}\left(M_{i}(A)\right)+\delta^{A} C(A) \leq \\
& C_{I}\left(M_{A}(A)\right)+\frac{\delta C_{L}\left(M_{A}(A)\right)}{1-\delta}+\sum_{i=2}^{A+1} \delta^{i} C_{I}\left(M_{i}(A+1)\right)+\delta^{A+2} C(A+1)
\end{aligned}
$$

and

$$
\begin{aligned}
& C_{I}\left(M_{A-1}(A)\right)+\frac{\delta C_{L}\left(M_{A}(A)\right)}{1-\delta}+\sum_{i=2}^{A} \delta^{i} C_{I}\left(M_{i}(A)\right)+\delta^{A+1} C(A) \leq \\
& \frac{C_{L}\left(M_{A-1}(A)\right)}{1-\delta}+\sum_{i=1}^{A-2} \delta^{i} C_{I}\left(M_{i}(A-1)\right)+\delta^{A-1} C(A-1)
\end{aligned}
$$

(17a) compares costs of an amnesty in period $A$ with an amnesty in period $A+1$, when migrants expect the amnesty in period $A$. (17b) looks one period earlier, and compares the cost of waiting until the expected time for an amnesty, and proclaiming an immediate amnesty. The same tradeoffs discussed above continue to be present.

\section{A Delayed Amnesty}

An often-used strategy is to declare an amnesty only for those who can prove that they have been in the country for some minimum period. Thus, for example the 1986 U.S. amnesty required proof of residence in the U.S. from at latest January 1, 1982, and the Dutch 1995 amnesty required proof of presence for at least 6 years.

The aim of such a plan is to limit the effect of the amnesty on the desire of migrants to enter the country in order to be eligible for the amnesty. Say the amnesty is only for those who have been in the country for at least $\tau$ years. Then the lifetime value of immigrating depends on when one migrated. If he migrated before the cutoff date, e.g., $e \geq \tau$ periods before the amnesty, then income is given by (12). However, if he migrated after the cutoff date, he will not become permanent until the next amnesty, so his lifetime income is given by:

$$
\begin{aligned}
& V_{i}^{H}(e)=N W_{i}^{S}+\left(1-P_{e}^{B}\right) \\
& \quad\left[\left(1+\sum_{h=1}^{e+A} \prod_{k=1}^{h}\left(1-P_{e+k}^{I}\right)+(N-e-A)\right)\left(W^{I}-W_{i}^{S}\right)-C_{D}\left(1-\prod_{k=1}^{e+A}\left(1-P_{e+k}^{I}\right)\right)\right] .
\end{aligned}
$$


The effect of such a plan is that all those who fall into this latter category will have a greatly lessened incentive to migrate.

The other side of the coin, of course, is that such a plan limits the benefit from the amnesty, since all those who entered the country during this "incubation" period remain in the country, and remain illegal. Thus, the stock of illegals is reduced, but not to zero. The stock of immigrants over time is exhibited in Figure 3. Note that, compared to Figure 2, the stock rises slower due to the decreased incentive to migrate, but is also falls less after an amnesty.

The government would like to set internal and border control allocations, an amnesty frequency, and an incubation period that brings the cost from illegal immigrants to a minimum. Thus, in an analogous manner to that above, the government would like to minimize

$$
C(A, \tau)=\frac{C_{L}\left(M_{A}^{L}(A)\right)}{1-\delta}+C_{I}\left(M_{A}^{I}(A)\right)+\sum_{i=1}^{A-1} \delta^{i} C_{I}\left(M_{i}(A, \tau)\right)+\delta^{A} C(A, \tau),
$$

where $M_{A}^{L}(A)$ and $M_{A}^{I}(A)$ are, respectively, the stocks of legal and illegal migrants remaining after the amnesty is granted. Conditions analogous to (16) and (17) will need to hold for this to be an equilibrium.

\section{E. A Limited Amnesty}

Many countries plagued by illegal immigration are reluctant to grant the type of amnesty granted in, for instance, the U.S. (where citizenship was granted) because they are not interested in having these illegals become citizens in their country. For these countries, the goal of the amnesty is often to rid the country of these undesirables. To this end, they devise an amnesty that will be sufficiently attractive to entice the illegal immigrants to come forward, while at the same time limiting their duration in the country. A limited amnesty is just such a plan, whereby workers are given a permit to remain and work in the country for a limited period of time, and are then required to leave once the permit has expired. ${ }^{8}$ Thus, for example, the Greek

\footnotetext{
${ }^{8}$ Any such plan must lend for the contingency that the worker will decide to overstay his permit, and will disappear into the economy and once again become an illegal immigrant. Thus, the granting of such a permit must include a mechanism that will allow the authorities the ability to enforce the departure of these illegal aliens. One such mechanism is the posting of a bond by the worker or his employer that is forfeited if the worker does not leave the country on time. For the effects of such bonds on illegal immigrants and their employers, see Epstein, Hillman and Weiss (1999).
} 
amnesty in 1998 was comprised of two stages. ${ }^{9}$ In the first stage workers were invited to submit applications for a temporary residence permit (a white card), and in the second, they could apply for a green card if they could prove that they had worked for at least 40 days between January and July 1998. The green card enabled the worker to remain 1-3 years, with subsequent renewal for two years possible. Special provisions also existed for the granting of five-year permits. The $43 \%$ of those with white cards who were not granted green cards and who remained in the country are again considered illegal. ${ }^{10}$

A limited amnesty introduces a new consideration into the model. Until now, all those eligible for an amnesty requested the amnesty. With a limited amnesty, however, those workers with a longer horizon will choose to bypass the amnesty, and instead remain illegal. In particular, the amnesty will certainly be accepted by anyone whose remaining work-life is shorter than the length of the work permit, but will tend to be rejected by those who will continue working for many years after the permit expires.

Consider, then, an illegal worker, $i$, with a remaining work-life of $X$ years, being offered a permit for $Y$ years, $Y<X$. He will accept the offer if:

(20) $\left(W^{I}-W_{i}^{S}\right) Y \geq\left(W^{I}-W_{i}^{S}\right) \sum_{i=1}^{X-1} \prod_{k=1}^{i}\left(1-P_{k}^{I}\right)-C_{D}\left(1-\prod_{k=1}^{X-1}\left(1-P_{k}^{I}\right)\right)$.

Note that our assumption that the worker's wage does not change once becoming legalized (see fn. 8), in particular limits the desirability of such a program. Were we to make the wage once legalized higher than when illegal, the number of people coming forward to accept this offer of amnesty would increase. The qualitative results, however, would not change.

There will also be an effect on those intending to migrate. The expected income of a potential immigrant will be equal to

\footnotetext{
${ }^{9}$ See Trends in International Migration, 1999.

${ }^{10}$ Korea, for instance, took a slightly different route. In their 1997-8 and 1999 amnesties they did not grant work permits, but rather allowed the illegal residents to leave the country without risking sanctions. This can be incorporated in our model by setting $C_{D}=0$ if you accept the amnesty.
} 


$$
\begin{array}{r}
\operatorname{Max}\left\{N W_{i}^{S}+\left(1-P_{e}^{B}\right)\left[\left(1+\sum_{h=1}^{e} \prod_{k=1}^{h}\left(1-P_{e+k}^{I}\right)+Y \prod_{k=1}^{e}\left(1-P_{e+k}^{I}\right)\right)\left(W^{I}-W_{i}^{S}\right)\right.\right. \\
\left.-C_{D}\left(1-\prod_{k=1}^{e}\left(1-P_{e+k}^{I}\right)\right)\right] \\
\left.N W_{i}^{S}+\left(1-P_{e}^{B}\right)\left[\left(1+\sum_{h=1}^{N-1} \prod_{k=1}^{h}\left(1-P_{e+k}^{I}\right)\right)\left(W^{I}-W_{i}^{S}\right)-C_{D}\left(1-\prod_{k=1}^{N-1}\left(1-P_{e+k}^{I}\right)\right)\right]\right\}
\end{array}
$$

The first term in the brackets give the expected income if the worker accepts the amnesty he will be offered, and the second term is the expected income if he does not. This latter term is identical to (10).

The result of this type of amnesty is that, in most cases, the amnesty will not rid the country of all illegal workers. Some will remain illegal, and continue to inflict the same costs upon the host country as in the original model. However, the incentive to migrate to the country is less than with a full amnesty, so again the stock of illegals in the country can be expected to vary as in Figure 3.

Interestingly, such a plan will actually make the incomes of those who do not accept the amnesty higher because government allocations will be shifted towards border controls and away from internal controls. This occurs because the existence of an amnesty increases flows, but the amnesty itself lowers the stock. Thus, the essence of this amnesty limits its degree of success.

Much as in the pervious section, the government would like to allocate resources and set the length of the temporary work permit and of the amnesty frequency such that it minimizes costs from the immigrants (both illegal and legal). In order to do so, the government should take into account the effect the length of the permit has on the percentage of people that will accept the amnesty offer, and the effect on new migration.

It is also possible to combine a limited amnesty with a delayed amnesty. As discussed above, the goals of these two types of amnesty are different. Those using a limited amnesty are interested in getting rid of as many migrants as they can, while those using a delayed amnesty tend to desire the naturalization of the migrants who have been in the country for a sufficiently long period. Perhaps for this reason, there have not, to our knowledge, been amnesties that have combined these two arrangements. It is possible, however, that the two could be used in tandem in order to minimize costs. From a modeling perspective, this would mean simply combining this 
and the last section, and minimizing costs over three arguments - the frequency of the amnesties, the incubation period, and the length of the temporary permit. The qualitative results would not change.

\section{Extensions}

\section{$\underline{\text { A. Intertemporal budget transfers }}$}

In Section II we considered a situation in which there was no amnesty, and the budget was fixed in each period. Consider now the effect of a budget that is fixed for the entire period, but can be transferred intertemporaly. In this case, even without considering an amnesty, the simple solution inherent from Lemma 1 may not hold. Equation (3) continues to be the objective function, but the third constraint now becomes:

$$
\sum_{i=0}^{T}\left(E_{i}^{B}+E_{i}^{I}\right) \leq \sum_{i=0}^{T} E_{i}
$$

We thus rewrite the objective function as:

$$
\underset{E_{i}^{B}, E_{i}^{I}, \lambda}{\operatorname{Min}} L=\sum_{k=0}^{T} \alpha_{k} \sum_{i=0}^{k} m_{i}\left(1-P_{i}^{B}\left(E_{i}^{B}\right)\right) \prod_{j=i+1}^{k}\left(1-P_{j}^{I}\left(E_{j}^{I}\right)\right)+\lambda\left(\sum_{i=0}^{T} E_{i}-\sum_{i=0}^{T}\left(E_{i}^{B}+E_{i}^{I}\right)\right),
$$

where $\lambda$ is a LaGrange multiplier. The first-order conditions are:

$$
\begin{gathered}
\frac{\partial L}{\partial E_{i}^{B}}: \quad-\left[\alpha_{i}+\sum_{k=1}^{T-i} \alpha_{i+k} \prod_{j=1}^{k}\left(1-P_{i+j}^{I}\right)\right]\left(P_{i}^{B}\right)^{\prime} m_{i}-\lambda=0 \\
\frac{\partial L}{\partial E_{i}^{I}}:-\left[\alpha_{i}+\sum_{k=1}^{T-i} \alpha_{i+k} \prod_{j=1}^{k}\left(1-P_{i+j}^{I}\right)\right]\left(P_{i}^{I}\right)^{\prime} M_{i-1}-\lambda=0
\end{gathered}
$$

and condition (9). Comparing (11) and (12) for any given $i$, we get condition (8) again - independent of the amount allocated to a certain period, the allocation within the period is the same as before, for the same reasons. Comparing the allocation across periods is more difficult, and without further specifying the variables little can be said. We will, however consider two cases. Under the assumption that the flow $(m)$ is constant over time, we consider the case where there is no time preference (i.e., all the $\alpha_{i}$ 's are equal), and the case where only the stock at the end of the period (possibly when a new election is to be held) is of interest.

\section{i. No time preference}


If all periods are given equal weight, then $\alpha_{k}=1 /(T+1)$, so the first order condition can be rewritten as:

$$
\begin{aligned}
& \text { (24') } \frac{\partial L}{\partial E_{i}}:-\frac{1}{T+1}\left[1+\sum_{k=1}^{T-i} \prod_{j=1}^{k}\left(1-P_{i+j}^{I}\right)\right]\left(P_{i}\right)^{\prime} m_{i}-\lambda=0 \text {; and } \\
& \text { (25') } \frac{\partial L}{\partial E_{i}^{I}}:-\frac{1}{T+1}\left[1+\sum_{k=1}^{T-i} \prod_{j=1}^{k}\left(1-P_{i+j}^{I}\right)\right]\left(P_{i}^{I}\right)^{\prime} M_{i-1}-\lambda=0
\end{aligned}
$$

This yields the following proposition:

Proposition 3: Beginning below steady-state, with a constant flow of immigrants, and when each period is of equal importance, allocations to border control will decrease over time, while the direction of change in allocations to internal control is ambiguous. In addition, as long as the flow of migrants is nondecreasing over time the ratio of expenditures on border control to internal control decreases over time.

Proof: Comparing the first order condition (24') over two consecutive periods, we get (26) $\left[1+\sum_{k=1}^{T-i} \prod_{j=1}^{k}\left(1-P_{i+j}^{I}\right)\right]\left(P_{i}^{B}\right)^{\prime}=\left[1+\sum_{k=1}^{T-i-1} \prod_{j=1}^{k}\left(1-P_{i+1+j}^{I}\right)\right]\left(P_{i+1}^{B}\right)^{\prime}$.

The bracketed term on the RHS is clearly smaller than that on the LHS, so the second term on the RHS must be larger. For this to occur, it must be that $E_{k+1}^{B}<E_{k}^{B}$. Comparing (23') for two consecutive periods:

(27) $\left[1+\sum_{k=1}^{T-i} \prod_{j=1}^{k}\left(1-P_{i+j}^{I}\right)\right]\left(P_{i}^{I}\right)^{\prime} M_{i-1}=\left[1+\sum_{k=1}^{T-i-1} \prod_{j=1}^{k}\left(1-P_{i+1+j}^{I}\right)\right]\left(P_{i+1}^{I}\right)^{\prime} M_{i}$.

Since $M_{k} \geq M_{k-1}$, it is not clear whether expenditures increase or fall. The last part of the proposition follows directly from Lemma 2.

Q.E.D.

Decreasing border control expenditures occur because earlier arrivals affect the stock for more periods, so it is more efficient to reduce the stock during the earlier periods rather than in later periods when their effect is for a more limited time period. This effect would seem to exist for internal controls also, but there is an opposing 
effect due to the growing size of the stock, making internal controls more crucial in later periods.

Note that, in keeping with our discussion of amnesties above, if the flow of migrants increases over time, allocations to both border and internal controls may still rise.

\section{ii. Preference for the last period}

In settings such as elections, there is often significant stress placed on occurrences during an election year. This is the reason for the well-known finding of increased governmental expenditures (particularly at the municipal level) during election years (see, for example, Nordhaus, 1975, Frey and Schneider, 1978, Rosenberg, 1992, and Rozevitch and Weiss, 1993). This idea extends to any issue pertinent to a campaign, with illegal immigration being no exception. It would be difficult for a challenger to an office to make a case of the level of illegal immigration a few years earlier. Clearly, the current state of affairs is what voters are concerned with. We thus propose as follows:

Proposition 4: When the stock in the last period is the only concern of the government, and the flow of migrants is nondecreasing over time, allocations to both border control and internal control will increase over time.

Proof: Under this setting, the optimization problem is simplified, as $\alpha_{T}=1$, and all other $\alpha_{i}=0$. The first order conditions become:

(24") $\frac{\partial L}{\partial E_{i}^{B}}:-\left[\prod_{j=1}^{T-i}\left(1-P_{i+j}^{I}\right)\right]\left(P_{i}^{B}\right)^{\prime} m_{i}-\lambda=0$; and

(25") $\frac{\partial L}{\partial E_{i}^{I}}:-\left[\prod_{j=1}^{T-i}\left(1-P_{i+j}^{I}\right)\right]\left(P_{i}^{I}\right)^{\prime} M_{i-1}-\lambda=0$;

Compare now two consecutive period, $k$ and $k+1$, and assume that $m_{k} \leq m_{k+1}$. From (24") we see that in equilibrium:

$$
\left[\prod_{j=1}^{T-k}\left(1-P_{k+j}^{I}\right)\right]\left(P_{k}^{B}\right)^{\prime} m_{k}=\left[\prod_{j=2}^{T-k}\left(1-P_{k+j}^{I}\right)\right]\left(P_{k+1}^{B}\right)^{\prime} m_{k+1}, \text { or }
$$




$$
\left(1-P_{k+1}^{I}\right)\left(P_{k}^{B}\right)^{\prime} m_{k}=\left(P_{k+1}^{B}\right)^{\prime} m_{k+1}
$$

Since the first term is strictly less than one and the second derivative of $P_{i}^{B}$ is strictly negative, it is clear that $E_{k+1}^{B}>E_{k}^{B}$.

With respect to internal controls, a comparison of two consecutive years yields:

$$
\left(1-P_{k+1}^{I}\right)\left(P_{k}^{I}\right)^{\prime} M_{k-1}=\left(P_{k+1}^{I}\right)^{\prime} M_{k}
$$

Since the population of illegal immigrants grows until the steady state and then stays constant, $M_{k} \geq M_{k-1}$. Hence, from (28) it is immediate that $E_{k+1}^{I}>E_{k}^{I}$. Q.E.D.

The logic behind the border control result is that immigrants who enter at an earlier period may still be caught and deported later on, so it is less important to catch them at the border. Those who manage to enter closer to the election year, however, will probably still be around at the end of the period, so it becomes more important to keep them out. With respect to internal controls the larger the stock the more illegals will be caught and deported, so expenditures on internal control become more cost efficient. Again, the possibility of an amnesty will strengthen this result since flows will tend to increase over time, although the increasing budgets allocated to apprehension may dampen this increased desire to migrate. ${ }^{11}$

\section{B. Alternative Formulations of Heterogeneity}

In the model above (Section IIB) we assumed that potential migrants were drawn from a population of workers who were heterogeneous in their wages. An alternative modelling would have source country wages identical (they could all, for instance, be unemployed in their home countries), but they could have differing levels of other traits. For instance, their skills could differ, in which case the better workers would be the first to migrate. Alternatively, even if workers are homogeneous in abilities, they could differ in their attachement to the source country. Thus, married people would be less likely to move, particularly if they have young children. Also, those with elderly parents might be less inclined to abanon them.

\footnotetext{
${ }^{11}$ It will not, though, affect the gross flow in the last year before the amnesty since internal control will not be effective for them.
} 
An additional alternative deserves further development, and that is differing levels of risk aversion. In the model we assumed workers are risk neutral, and so considered only expected income. If workers, however, have differing levels of risk aversion (or risk loving), a self-selection equilibrium can be had without resorting to heterogeneous workers. Since there is risk in migrating - the worker may not get into the country (border control) or may be apprehended and deported (internal control) those who are least risk-averse will be the first to migrate. The result of this is that those who come may be the most risk-loving of the potential migrants - which may help explain why so many of them end up involved in risky activities, such as criminal activities.

\section{Uncertainty}

An interesting empirical aspect of amnesties is that there tend to be migrants who come forward to get an amnesty, but are then denied the amnesty and instead shipped out of the country. This seems to be an unintentional (or perhaps intentional) side effect of the amnesty. In this section we consider whether this can be an equilibrium strategy.

Say potential candidates for an amnesty are distributed along an additional scale with respect to some variable that is of concern to the authorities. For instance, authorities may say that those found to have been involved in illegal activities of some sorts (theft, drugs, etc.) will be brought before a board to decide whether to grant them amnesty or to deport them. In this case, those clearly not involved will step forward, those heavily involved will not, but those in the middle will step forward only if their expected gain is positive.

From Equations (12) and (10) we can discern that the gain from being granted an amnesty to a worker depends on how many periods he has remaining in his worklife, and is given by:

$$
\left(-\sum_{i=A}^{N-1} \prod_{k=A}^{i}\left(1-P_{k}^{I}\right)+(N-A)\right)\left(W^{I}-W_{i}^{S}\right)+C_{D}\left(1-\prod_{k=A}^{N-1}\left(1-P_{k}^{I}\right)\right) .
$$

The first set of terms is the addition wage received over the migrant's remaining worklife, and the second set of terms is the expected savings from the fact that it is clear that he will not have to bear the deportation cast once he has received the 
amnesty. If, however, the worker who steps forward for an amnesty is denied that amnesty and, instead, deported, his expected loss (relative to had he not come forward) will be:

$$
\left(\sum_{i=A}^{N-1} \prod_{k=A}^{i}\left(1-P_{k}^{I}\right)\right)\left(W^{I}-W_{i}^{S}\right)+C_{D}\left(\prod_{k=A}^{N-1}\left(1-P_{k}^{I}\right)\right) .
$$

The first set of terms, again, being the loss in expected wage, and the second set of terms being the deporting cost. The reason this latter cost is multiplied by $\prod_{k=A}^{N-1}\left(1-P_{k}^{I}\right)$ is because while the cost will certainly have to be paid, there was a probability that it would have been paid anyway (had he been caught), and so the loss from coming forward is just the difference.

Combining (31) and (32), and defining $P(A)$ as the probability of being granted the amnesty given the migrant's place on the scale, the migrants who will come forward to request amnesty will be those for whom:

$$
\left(-\sum_{i=A}^{N-1} \prod_{k=A}^{i}\left(1-P_{k}^{I}\right)+P(A)(N-A)\right)\left(W^{I}-W_{i}^{S}\right)+C_{D}\left(P(A)-\prod_{k=A}^{N-1}\left(1-P_{k}^{I}\right)\right)>0 .
$$

Isolating $P(A)$, those who will come forward will be those for whom:

$$
P(A)>\frac{\sum_{i=A}^{N-1} \prod_{k=A}^{i}\left(1-P_{k}^{I}\right)}{N-A+C_{D}}+\frac{C_{D} \prod_{k=A}^{N-1}\left(1-P_{k}^{I}\right)}{\left(N-A+C_{D}\right)\left(W^{I}-W_{i}^{S}\right)} .
$$

This will include two groups - those for whom the probability of gaining the amnesty is high and those for whom the alternative wage at home is sufficiently high so that the risk is relatively low.

The outcome of such a "fuzzy" amnesty declaration will be that there will be some deported, but they will tend to be those who have committed the least grievous crimes rather than those who the country would truly like to rid itself of. This will also be true since many of those will be earning higher salaries doing what they are doing than if they became legal (and, as a result, visible).

\section{Summary}

This paper presented a first attempt at understanding the many issues involved in the granting of an amnesty to illegal immigrants. We have considered government behavior with respect to allocations for limiting infiltration (border control) and 
apprehending infiltrators (internal control) and with respect to the granting of amnesties, the timing of amnesties, and limitations of those amnesties. We have been able to reach some conclusions with respect to allocations and the flow of immigrants, and have gained insight into the timing and manner of amnesties. More specific conclusions would require more specific functional specifications. We have also considered various extensions such as intertemporal transfers of policing funds, riskaversion, and "fuzziness" in declarations regarding eligibility for an amnesty aimed at apprehending and deporting undesirables.

The paper has numerous empirical implications regarding changing allocations over time, changes in migration flows over time, and differences between countries that grant amnesties and those that do not (perhaps because the stock or flow of illegals does not warrant such a measure). We leave this to future research.

The paper yields some policy implications. Countries with illegal migration problems need to define their goals before embarking on an amnesty program. Those interested in ridding themselves of the illegal workers will be best off with some type of limited amnesty whereby they grant limited work permits that require the immigrant to leave the country at the end of the period. For such a plan to work, however, it is necessary to guarantee that the worker can, in fact, be found at the end of the period, and that he does not simply blend back into the background. One way to do this is by requiring a bond to be posted by the worker (or by his employer) that is forfeited if the person does not leave. If the bond is sufficiently high, the worker will be likely to return to his home country.

A country interested, instead, in absorbing the "worthy" immigrants (often defined in terms of time spent in the country and the worker's past employment record) may want to consider a delayed amnesty, whereby only those fulfilling these requirements are granted the amnesty. An option open to all countries is to use a "fuzzy" amnesty, whereby the exact criteria to be granted the amnesty (whether a temporary work permit or citizenship) are not clearly defined, allowing the country to deport some of the more undesirable immigrants. Such a plan, however, will likely exhibit only limited success, as the most undesirable people (e.g., the hard criminals) will be unlikely to come forward, since they know that it is highly unlikely that they will satisfy the requirements. 


\section{References}

Andreoni, J. (1991) “The Desirability of a Permanent Tax Amnesty," Journal of Public Economics, 45, 143-59.

Borjas, G. (1994) “The Economics of Immigration," Journal of Economic Literature, $32,1667-1717$.

Borjas, G. (1995) “The Economic Benefits from Immigration," Journal of Economic Perspectives, 9, 3-22.

Chiswick, B.R., and Miller, P.M. (1999) "Ethnic Networks and Language Proficiency among Immigrants," Journal of Population Economics, 12, 19-35.

Djajic, S. (1999) "Dynamics of Immigration Control," Journal of Population Economics, 12, 45-61.

Epstein, G.S., and Hillman, A.L. (2000) "Social Harmony at the Boundaries of the Welfare State, Immigration and Social Transfers," IZA working paper 168.

Epstein, G.S., Hillman, A.L. and Weiss, A. (1999) "Creating Illegal Immigrants," Journal of Population Economics 12, 3-21.

Ethier, W.J. (1986) "Illegal Immigration: The Host Country Problem," American Economic Review, 76, 56-71.

Frey, B., and Schneider, F. (1978) “An Empirical Study of Politico-economic Interaction in the U.S.," Review of Economics and Statistics, 60, 174-183.

Gavosto, A., Venturini, A. and Villosio C. (1999) "Do Immigrants Compete with Natives?" Labour 13, 603-621.

Hanson, G.D., Robertson R., and Spilimergo A. (1999) "Does Border Enforcement Protect USA workers from Illegal Immigrants?” NBER working paper no. 7054.

Hillman, A.L., and Weiss, A. (1999) "A Theory of Permissible Illegal Immigration," European Journal of Political Economy, 15, 585-604.

Malik, A.S., and Schwab, R.M. (1991) “The Economics of Tax Amnesties," Journal of Public Economics, 41, 29-49.

Myers, G.M., and Papageorgiou Y.Y. (2000) "Immigration Control and Welfare State," Journal of Public Economics, 75, 183-207.

Nordhaus, W. (1975) “The Political Business Cycle," Review of Economic Studies, 42, 169-190. 
Rosenberg, J. (1992) "Rationality and the Political Business Cycle: The Case of Local Government," Public Choice, 73, 71-81.

Rozevitch, S., and Weiss, A. (1993) "Beneficiaries from Federal Transfers to Municipalities: The Case of Israel," Public Choice, 76, 335-346.

Venturini, A. (1999) "Do immigrants working illegally Reduce the Natives' Legal Employment? Evidence from Italy," Journal of Population Economics, 12, 135-154.

Zimmermann, K.F. (1995) "Tackling the European Migration Problem," Journal of Economics Perspectives, 9, 45-62. 
Table 1

Selected Regularization Programs

\begin{tabular}{|c|c|c|c|}
\hline Country & Year & $\begin{array}{l}\text { Number of } \\
\text { regularized } \\
\text { immigrants }\end{array}$ & Details \\
\hline Argentina & 1994 & 210,000 & \\
\hline \multirow[t]{2}{*}{ France } & $1981-2$ & 121,100 & \\
\hline & $1997-8$ & 77,800 & 143,000 applicants \\
\hline Greece & $1997-8$ & 374,000 & $\begin{array}{l}\text { Granted White cards, of which } 220,000 \\
\text { applied for green cards. Permits to remain } \\
\text { up to } 5 \text { years. }\end{array}$ \\
\hline \multirow[t]{4}{*}{ Italy } & $1987-8$ & 118,700 & \\
\hline & 1990 & 217,700 & \\
\hline & 1996 & 227,300 & 258,761 applicants \\
\hline & 1998 & 350,000 & Number of applications received \\
\hline \multirow[t]{2}{*}{ Korea } & $1997-8$ & 45,000 & Allowed to leave without sanctions \\
\hline & 1999 & $?$ & \\
\hline \multirow[t]{2}{*}{ Portugal } & $1992-3$ & 39,200 & \\
\hline & 1996 & 21,800 & \\
\hline Romania & 1997 & 30,000 & Extended temporary residence visas \\
\hline \multirow[t]{3}{*}{ Spain } & $1985-6$ & 43,800 & Number of applications received \\
\hline & 1991 & 110,100 & \\
\hline & 1996 & 21,300 & \\
\hline \multirow[t]{2}{*}{ United States } & 1986 & $2,684,900$ & $\begin{array}{l}\text { 1989-1996 under } 1986 \text { Immigration and } \\
\text { Reform Control Act. Excludes } \\
\text { dependents. }\end{array}$ \\
\hline & $1997-8$ & 405,000 & $\begin{array}{l}\text { Estimates. Nicaraguan Adjustment and } \\
\text { Central American Relief Act (1997), and } \\
\text { Haitian Refugee Immigration Fairness Act } \\
\text { (1998). }\end{array}$ \\
\hline
\end{tabular}

Sources: Trends in International Migration, OECD 1999. 
Figure 1
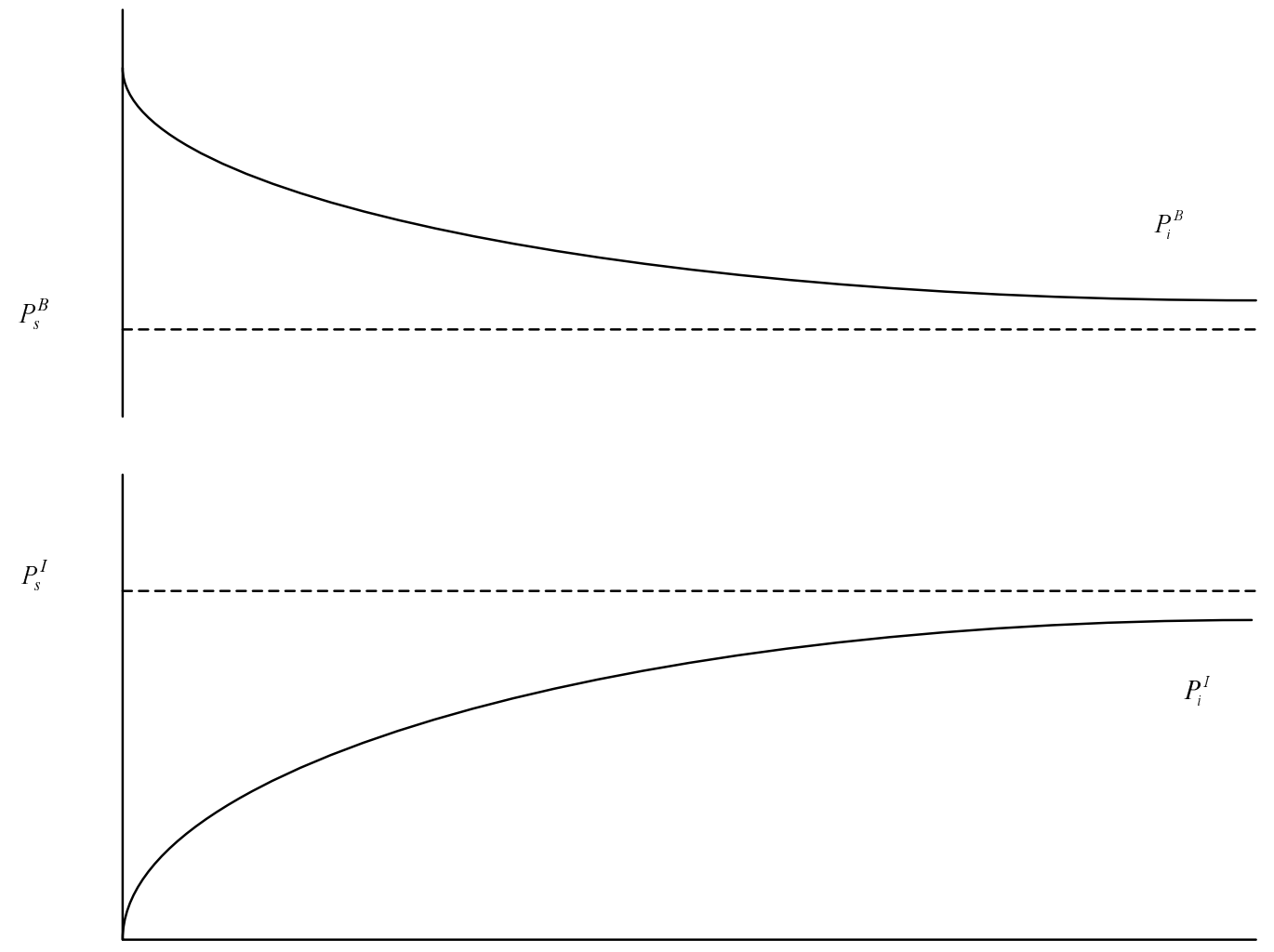

Period
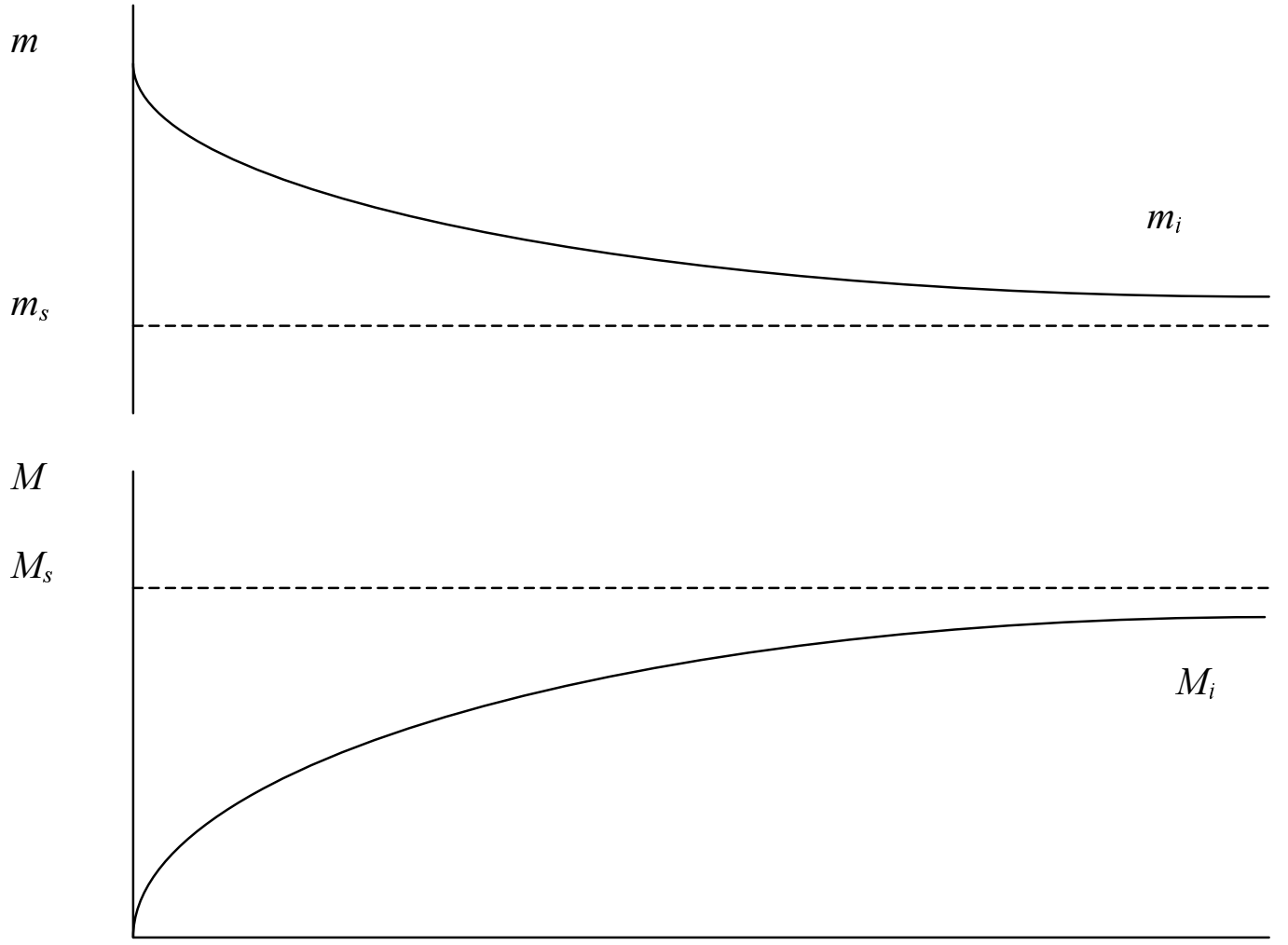

Period 
Figure 2

Amnesty

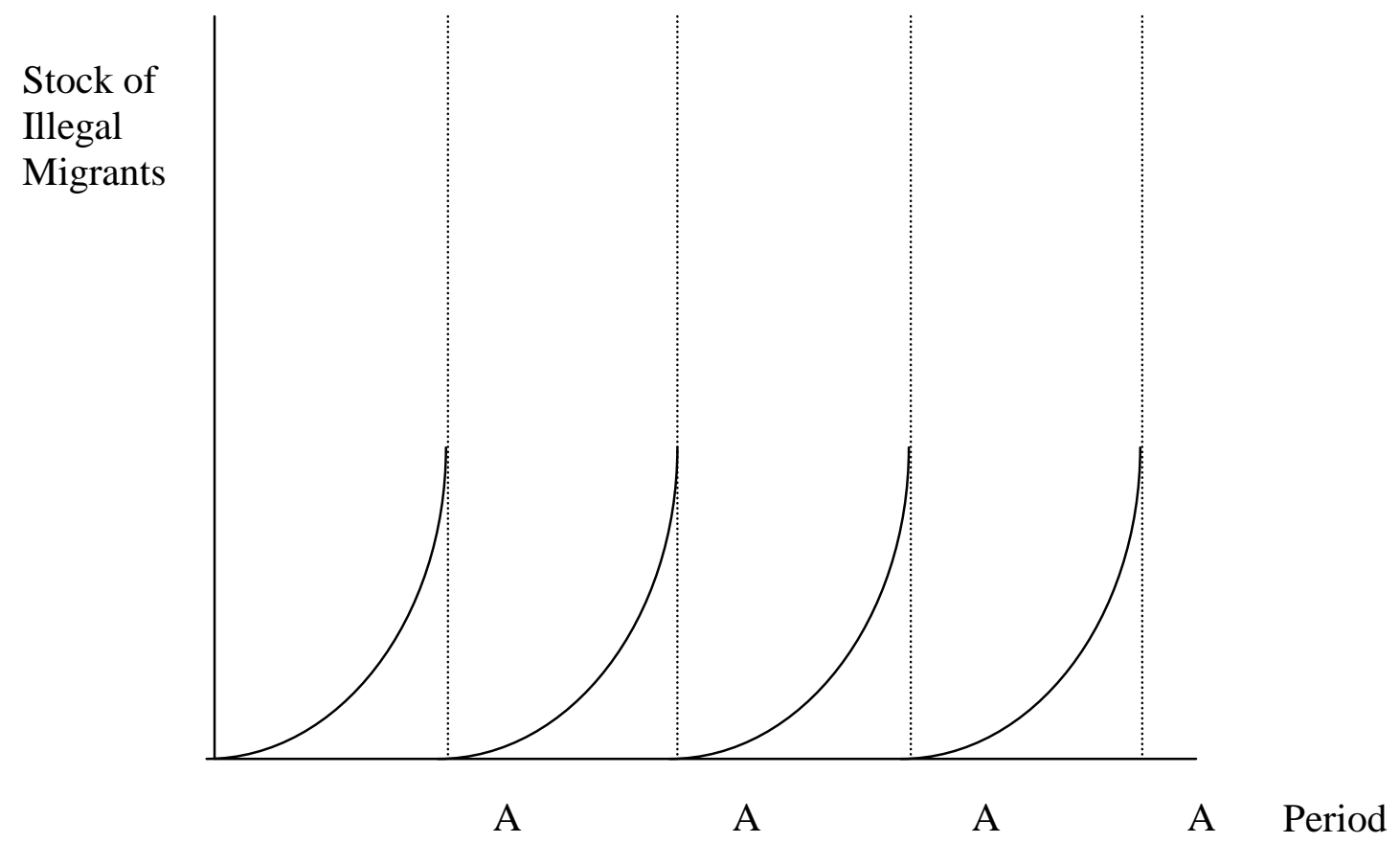


Figure 3

Delayed Amnesty

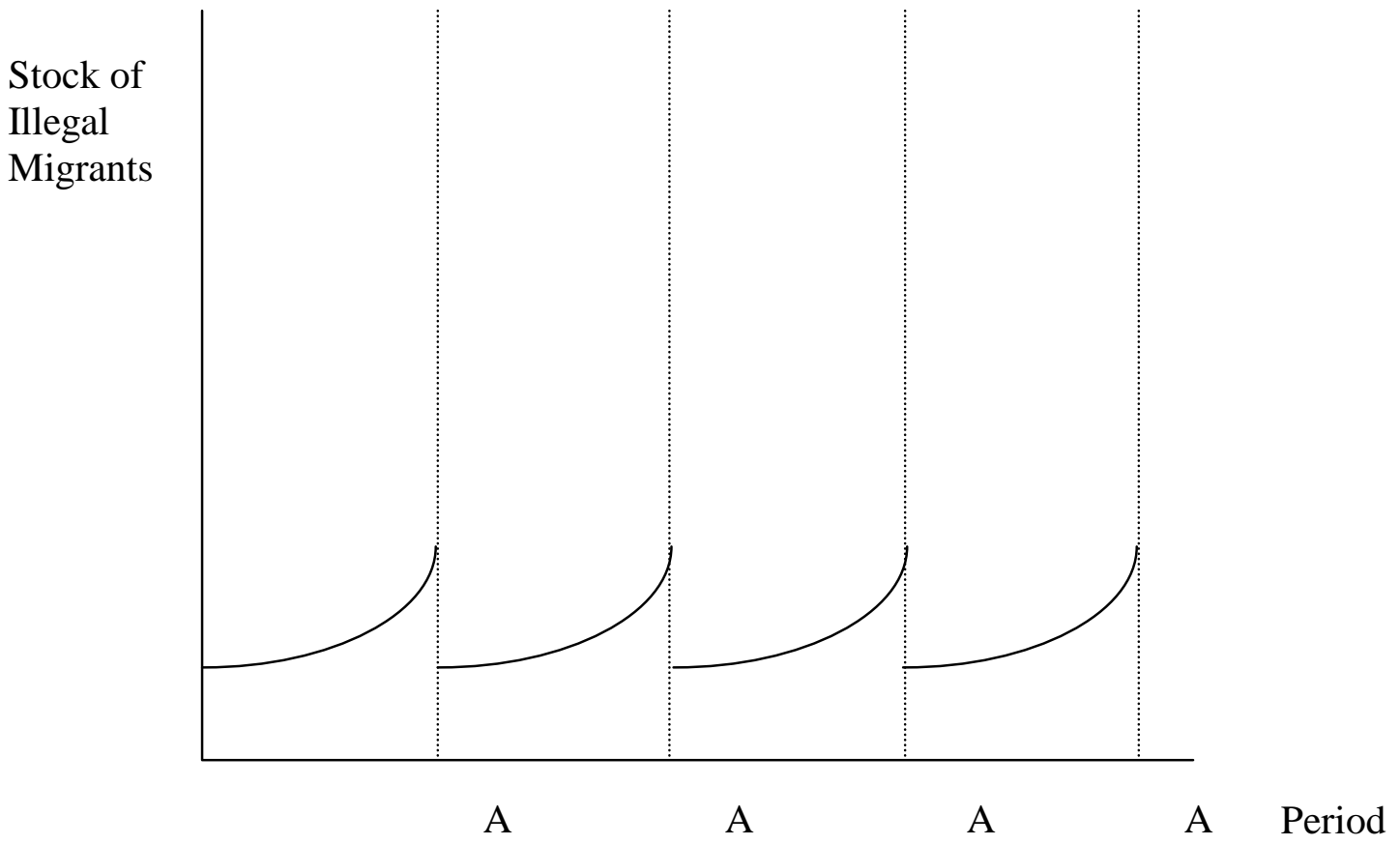




\section{IZA Discussion Papers}

\begin{tabular}{|c|c|c|c|c|}
\hline No & Author(s) & Titel & Area & Date \\
\hline 221 & C. Grund & Wages as Risk Compensation in Germany & 5 & $12 / 00$ \\
\hline 222 & W.P.M. Vijverberg & Betit: A Family That Nests Probit and Logit & 7 & $12 / 00$ \\
\hline 223 & $\begin{array}{l}\text { M. Rosholm } \\
\text { M. Svarer }\end{array}$ & $\begin{array}{l}\text { Wages, Training, and Job Turnover in a Search- } \\
\text { Matching Model }\end{array}$ & 1 & $12 / 00$ \\
\hline 224 & J. Schwarze & $\begin{array}{l}\text { Using Panel Data on Income Satisfaction to } \\
\text { Estimate the Equivalence Scale Elasticity }\end{array}$ & 3 & $12 / 00$ \\
\hline 225 & $\begin{array}{l}\text { L. Modesto } \\
\text { J. P. Thomas }\end{array}$ & $\begin{array}{l}\text { An Analysis of Labour Adjustment Costs in } \\
\text { Unionized Economies }\end{array}$ & 1 & $12 / 00$ \\
\hline 226 & P. A. Puhani & $\begin{array}{l}\text { On the Identification of Relative Wage Rigidity } \\
\text { Dynamics: A Proposal for a Methodology on } \\
\text { Cross-Section Data and Empirical Evidence for } \\
\text { Poland in Transition }\end{array}$ & $4 / 5$ & $12 / 00$ \\
\hline 227 & L. Locher & $\begin{array}{l}\text { Immigration from the Eastern Block and the } \\
\text { former Soviet Union to Israel: Who is coming } \\
\text { when? }\end{array}$ & 1 & $12 / 00$ \\
\hline 228 & $\begin{array}{l}\text { G. Brunello } \\
\text { S. Comi } \\
\text { C. Lucifora }\end{array}$ & $\begin{array}{l}\text { The College Wage Gap in } 10 \text { European } \\
\text { Countries: Evidence from Two Cohorts }\end{array}$ & 5 & $12 / 00$ \\
\hline 229 & $\begin{array}{l}\text { R. Coimbra } \\
\text { T. Lloyd-Braga } \\
\text { L. Modesto }\end{array}$ & $\begin{array}{l}\text { Unions, Increasing Returns and Endogenous } \\
\text { Fluctuations }\end{array}$ & 1 & $12 / 00$ \\
\hline 230 & L. Modesto & $\begin{array}{l}\text { Should I Stay or Should I Go? Educational } \\
\text { Choices and Earnings: An Empirical Study for } \\
\text { Portugal }\end{array}$ & 5 & $12 / 00$ \\
\hline 231 & G. Saint-Paul & The Economics of Human Cloning & 5 & $12 / 00$ \\
\hline 232 & $\begin{array}{l}\text { E. Bardasi } \\
\text { M. Francesconi }\end{array}$ & $\begin{array}{l}\text { The Effect of Non-Standard Employment on } \\
\text { Mental Health in Britain }\end{array}$ & 5 & $12 / 00$ \\
\hline 233 & $\begin{array}{l}\text { C. Dustmann } \\
\text { C. M. Schmidt }\end{array}$ & $\begin{array}{l}\text { The Wage Performance of Immigrant Women: } \\
\text { Full-Time Jobs, Part-Time Jobs, and the Role of } \\
\text { Selection }\end{array}$ & 1 & $12 / 00$ \\
\hline 234 & $\begin{array}{l}\text { R. Rotte } \\
\text { M. Steininger }\end{array}$ & $\begin{array}{l}\text { Sozioökonomische Determinanten extremistischer } \\
\text { Wahlerfolge in Deutschland: Das Beispiel der Eu- } \\
\text { ropawahlen } 1994 \text { und } 1999\end{array}$ & 3 & $12 / 00$ \\
\hline
\end{tabular}


236 R. Hujer

M. Caliendo

237 S. Klasen

I. Woolard

238 R. Euwals

A. Börsch-Supan

A. Eymann

239 F. Andersson

K. A. Konrad

240 W. Koeniger

241 W. Koeniger

242 G. Faggio

J. Konings

243

E. Brainerd

244 S. M. Fuess, Jr. M. Millea

245 F. Andersson

K. A. Konrad

246 E. Plug

W. Vijverberg

247 E. Plug

W. Vijverberg

248 P. M. Picard

E. Toulemonde

249

B. M. S. van Praag

P. Cardoso

250

T. J. Hatton

J. G. Williamson
Evaluation of Active Labour Market Policy:

6

$12 / 00$

Methodological Concepts and Empirical

Estimates

Surviving Unemployment without State Support: 3

$12 / 00$

Unemployment and Household Formation in

South Africa

The Saving Behaviour of Two Person House-

5

$12 / 00$

holds: Evidence from Dutch Panel Data

Human Capital Investment and Globalization in

Extortionary States

5

01/01

Labor and Financial Market Interactions: The

5

$01 / 01$

Case of Labor Income Risk and Car Insurance in the UK 1969-95

Trade, Labor Market Rigidities, and Government- 2 Financed Technological Change

$01 / 01$

Job Creation, Job Destruction and Employment 4

Growth in Transition Countries in the 90's

$01 / 01$

Economic Reform and Mortality in the Former

4

$01 / 01$

Soviet Union: A Study of the Suicide Epidemic in the 1990s

Pay and Productivity in a Corporatist Economy: 5

$01 / 01$

Evidence from Austria

Globalization and Human Capital Formation

5

$01 / 01$

Schooling, Family Background, and Adoption:

5

$01 / 01$

Does Family Income Matter?

Schooling, Family Background, and Adoption:

5

$01 / 01$

Is it Nature or is it Nurture?

The Impact of Labor Markets on Emergence and 2

Persistence of Regional Asymmetries

01/01

"Should I Pay for You or for Myself?"

3

01/01

The Optimal Level and Composition of

Retirement Benefit Systems

Demographic and Economic Pressure on

Emigration out of Africa 
254 H. Gersbach

A. Schniewind

255 H. Gersbach

A. Schniewind

T. Boeri

H. Brücker

257

T. Boeri

258

M. Rosholm

K. Scott

L. Husted

259

A. Ferrer-i-Carbonell

B. M.S. van Praag

260

P. Cahuc

F. Postel-Vinay

261

M. Lindahl

262

M. Lindahl

263

N. Datta Gupta

N. Smith

264

C. Dustmann

265

M. Rosholm

M. Svarer

C. Dustmann

O. Kirchkamp
Learning of General Equilibrium Effects and the Unemployment Trap

3

02/01

Product Market Reforms and Unemployment in 3 Europe

Eastern Enlargement and EU-Labour Markets: 2 Perceptions, Challenges and Opportunities

Transition with Labour Supply

4

02/01

The Times They Are A-Changin':

1

$02 / 01$

Organizational Change and Immigrant

Employment Opportunities in Scandinavia

Poverty in the Russian Federation

4

$02 / 01$

Temporary Jobs, Employment Protection and

$1 / 3$

02/01

Labor Market Performance

Home versus School Learning:

5

02/01

A New Approach to Estimating the Effect of Class Size on Achievement

Summer Learning and the Effect of Schooling:

5

02/01 Evidence from Sweden

Children and Career Interruptions:

5

02/01

The Family Gap in Denmark

Return Migration, Wage Differentials, and the

1

02/01 Optimal Migration Duration

Structurally Dependent Competing Risks

02/01

The Optimal Migration Duration and Activity Choice after Re-migration 
283 M. Hagedorn

A. Kaul

V. Reinthaler

284

H. Rapoport

A. Weiss

285

J. Jerger

C. Pohnke

A. Spermann

286 M. Fertig

C. M. Schmidt

287 P. Guggenberger

A. Kaul

M. Kolmar

288

D. A. Cobb-Clark

289

L. Cameron

D. A. Cobb-Clark

290

D. A. Cobb-Clark

M. D. Connolly

C. Worswick

291

R. T. Riphahn

292

E. Wasmer

293

D. Cobb-Clark

T. F. Crossley

294 Š. Jurajda

295
F. Duffy
P. P. Walsh

296 H. S. Nielsen

M. Rosholm

N. Smith

L. Husted
Welfare Analysis in a Schumpeterian Growth

Gut betreut in den Arbeitsmarkt?

5

04/01

Eine mikroökonometrische Evaluation der

Mannheimer Arbeitsvermittlungsagentur

First- and Second-Generation Migrants in

People Think

Efficiency Properties of Labor Taxation in a

3

04/01

Spatial Model of Restricted Labor Mobility

Getting Ahead: The Determinants of and Payoffs

5

$04 / 01$ to Internal Promotion for Young U.S. Men and Women

Old-Age Support in Developing Countries:

Labor Supply, Intergenerational Transfers and

Living Arrangements

The Job Search and Education Investments of

04/01 Immigrant Families

$05 / 01$

Cohort Effects in the Educational Attainment of Second Generation Immigrants in Germany: An Analysis of Census Data

Between-group Competition in the Labor Market and the Rising Returns to Skill: US and France 1964-2000

Gender, Comparative Advantage and Labor

05/01 Market Activity in Immigrant Families

Estimating the Effect of Unemployment

$05 / 01$ Insurance Compensation on the Labor Market Histories of Displaced Workers

Individual Pay and Outside Options:

05/01

Evidence from the Polish Labour Force Survey

4 
297 J. C. van Ours J. Veenman

298 P. Telhado Pereira P. Silva Martins

299 G. Brunello

C. Lucifora

R. Winter-Ebmer

300 A. Stutzer

R. Lalive

301 J. R. Frick

G. G. Wagner

302 G. S. Epstein

A. Weiss
The Educational Attainment of Second Generation 1 Immigrants in The Netherlands

Returns to Education and Wage Equations

5

06/01

The Wage Expectations of European College

5

06/01 Students

The Role of Social Work Norms in Job Searching

5

06/01 and Subjective Well-Being

Economic and Social Perspectives of Immigrant

1

06/01 Children in Germany

A Theory of Immigration Amnesties

1

06/01 